文
論 UDC $669.14 .018 .292: 539.42: 620.193: 620.174: 620.115 .842$

部分除荷をほどこした高強度鋼材の遅れ破壊強さにおよぼす 試験片形状の影響*

\author{
中佐啓治郎 ${ }^{* *} \cdot$ 木戸 光夫*** . 武井 英雄 $* * * *$
}

\title{
Effect of Specimen Shape on the Delayed Failure Strength of High Strength Steel Prestressed by Partial Unloading
}

Keijiro NAKasa, Mitsuo KIDo, and Hideo TAKeI

\section{Synopsis:}

The effects of two types of prestressing, i.e. partial unloading and perfect unloading, on the delayed failure strength have been investigated on various specimen configurations.

The results obtained are summarized as follows:

(1) Grack initiation time and $100 \mathrm{~h}$ delayed failure strength can be largely increased by two types o prestress methods, especially by partial unloading method, regardless of specimen thickness and notch root radius. The rate of increase of $100 \mathrm{~h}$ delayed failure strength by both prestress methods increases to converge to a certain value with increase of specimen thickness.

(2) In order to raise the $100 \mathrm{~h}$ delayed failure strength by both prestressing methods, it is necessary to increase the unloading stress to a critical value, $\left(\sigma_{\mathrm{a}}\right)_{\mathrm{c}}$, which increases with increase of specimen thickness and decrease of notch root radius.

1. 緒 言

微小な欠陥や鋭い切り欠きを有する高強度鋼材は，遅 れ破壊に対して非常に敏感であり，このことが高強度鋼 の使用に対する 1 つの大きな障害となつている，遅れ破 壊に対する抵抗性すなわち耐遅れ破壊性を改善する手段 としては，合金元素の添加や熱処理の改善などが考えら れているが1，いまだ決定的な方法はない，一方，部材 に予ひずみを付与する方法は，耐遅れ破壊性の改善にか なり有効であることが報告されているが2)3), 著者らも前 報4～6)に括いて，種々の予ひずみ法が遅れ破壊強さの向 上にどのように役立つかを調べ，荷重を試験荷重より大 きいある荷重に一度上昇させ，その荷重から部分的に除 荷して遅れ破壊試験を行う方法, すなわち“部分除荷法” が遅れ破壊強さの向上に非常に有効であることを明らか にした. 本研究では, この部分除荷法が試験片形状（板 厚や切り欠き底半径の大きさ）が異なる場合にも同様に 有効であるかどらかを調べ，この方法が実用可能かどう かを検討した.

\section{2. 実 験 方 法}

\section{$2 \cdot 1$ 材料および試験片}

実験に用いた材料は, 市販の Ni-Cr-Mo 鋼 8 種 (SNCM 8 ) の丸棒で, その化学成分を Table 1 に示 す. これを熱間鍛造後焼なまししてから，Fig. 1 に示 す形状寸法に機械加工し，さらにこれに熱処理 $\left(880^{\circ} \mathrm{C}\right.$ $30 \mathrm{~min}$ 間加熱油焼入れ，200 $\mathrm{C} 1 \mathrm{~h}$ 焼もどし) を施して 試験片とした。ただし，試験片の切り欠きおよび疲労き 裂は熱処理後につけた.なおこの試料の熱処理後の引張 り諸性質 (平行部長さ $80 \mathrm{~mm}$, 幅 $15 \mathrm{~mm}$, 厚さ 4.5 $\mathrm{mm}$ の平滑試験片による）は降伏強さ $155 \mathrm{~kg} / \mathrm{mm}^{2}$ $\left(1520 \mathrm{MP}_{\mathrm{a}}\right)$, 引張り強さ $193 \mathrm{~kg} / \mathrm{mm}^{2}\left(1890 \mathrm{MP}_{\mathrm{a}}\right)$, 伸 び $8.1 \%$ であつた.

\section{$2 \cdot 2$ 遅れ破壊試験}

実験には，片持ばり方式の遅れ破壊試験機を用い，所 定の曲げモーメントMを Fig. 1 に示す試験片の矢印方 向に加えた。腐食雾囲気には，イオン交換した純水 $(20$ $\left.{ }^{\circ} \pm 3^{\circ} \mathrm{G}\right)$ を用い，これを試験片に取り付けた塩化ビニー

* 昭和 53 年 4 月日本金属学会講演大会にて発表 昭和 54 年 10 月 18 日受付 (Received Oct. 18, 1979)

** 広島大学工学部 工博 (Faculty of Engineering, Hiroshima University)

*** 広島工業大学 (Hiroshima Institute of Technology, Miyake Itsukaichi-cho Saeki 738)

**** 広島大学工学部 理博 (Faculty of Engineering, Hiroshima University) 
Table 1. Chemical composition of specimen (wt \%).

\begin{tabular}{l|c|c|c|c|c|c|c|c|c}
\hline Mark & $\mathrm{C}$ & $\mathrm{Si}$ & $\mathrm{Mn}$ & $\mathrm{P}$ & $\mathrm{S}$ & $\mathrm{Ni}$ & $\mathrm{Cr}$ & $\mathrm{Mo}$ & $\mathrm{Fe}$ \\
\hline SNCM8 & 0.42 & 0.29 & 0.78 & 0.012 & 0.005 & 1.79 & 0.82 & 0.19 & Bal \\
\hline
\end{tabular}

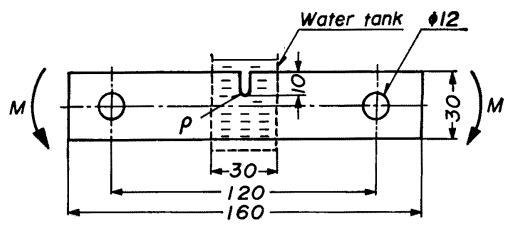

Thickness, $B=1.5,4.5,7.0,10.0$

$\rho=\sim 0($ F.C.) $0.3,1.0$

Fig. 1. Shape and size of specimen.
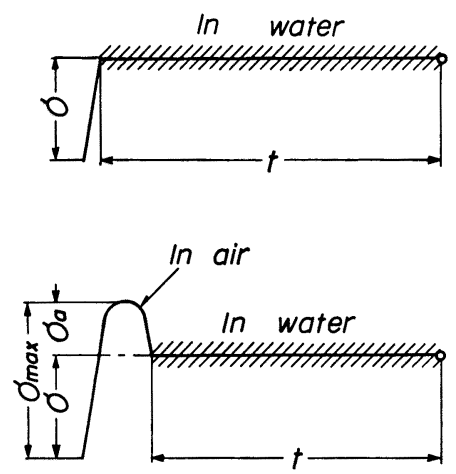

(I) Partial Unloading Method



(II) Perfect Unloading Method

Fig. 2. Schematic diagram indicating various prestressing methods.

ル製容器の中に滴下し，Fig. 1の試験片の破線で囲まれ る領域が常に水に接触するようにした. な打切り欠き底 から遅れ破壊き裂が発生する時期は, 前報5) と同様, 試 験機のアームのたわみが増加し始める時点とした. この とき切り欠き底に発生したき裂の大きさは板厚や切り欠 き底曲率半径により多少の違いがあつたが約 $0.5 \mathrm{~mm}$ あつた。

つぎに本研究で実施した予荷重法の概要を Fig. 2 に 示す. 同図の最上部の図は, 予荷重を与えない通常の遅 れ破壊試験での負荷方法を示したもので，ハッチングの
施してある部分は試験片が水中で一定の荷重を受けてい ることを示している. 同図 ( I ) の負荷方法は, 曲げ公称 応力 $\sigma$ (曲げモーメントを切り欠きがないとしたときの 断面係数で割つた值) を一度所定の最大応力 $\sigma_{\max }$ に市 で増加したのち， $\sigma_{\mathrm{a}}$ だけ部分的に応力を低下させ，そ のままその応力 $\sigma\left(=\sigma_{\max }-\sigma_{\mathrm{a}}\right)$ で遅れ破壊試験を行ら 方法で，著者らはこれを部分除荷法と名づけた5)。同図 （II）の方法は曲げ公称応力を $\sigma_{\max }$ に上昇させたのち， 一度荷重を零にして完全に除荷し，その後 $\left(\sigma_{\max }-\sigma_{\mathrm{a}}\right)$ に等しい所定の応力 $\sigma$ に再負荷して遅れ破壊試験を行う 方法である.この方法は従来よりょく知られているもの で2)3), 本研究ではこれを完全除荷法と呼ぶ.なお（I）拉 よび (II)の両方法とも, 最終的には最大応力 $\sigma_{\max }$ から 試験応力 $\sigma\left(\sigma_{\max }-\sigma_{\mathrm{a}}\right)$ へと， $\sigma_{\mathrm{a}}$ だけ除荷されている ことになるので以後 $\sigma_{\mathrm{a}}$ を除荷応力，また $\sigma_{\mathrm{a}}$ と $\sigma$ との 比 $\left(\phi=\sigma_{\mathrm{a}} / \sigma\right)$ を除荷比と呼ぶことにする. 本研究では, 数種の試験応力 $\sigma$ を選び， $\sigma_{\mathrm{a}}$ を種々に変化させて実験 を行い，遅れ破壞き裂発生時間が試験片の形状（板厚お よび切り欠き底半径の大きさ）によつてどのように変化 するかを調べた。

\section{3. 実 験 結 果}

\section{1 遅れ破壊き裂発生時間におよぼす試験片板厚の 影響}

焼入後 $200^{\circ} \mathrm{C}$ で焼もどした SNGM 8 の試験片につ いて，切り欠き底曲率半径 $\rho$ を $0.3 \mathrm{~mm}$ とし，板厚 $\beta$ を $1.5,7.0,10 \mathrm{~mm}$ と変化させて通常の遅れ破壊試験を行 い，静的公称曲げ応力 $\sigma$ と遅れ破壊き裂発生時間 $\boldsymbol{t}$ の関 係を調べた. その結果を Fig. 3 に示す.これによると 板厚が大きくなるにつれてき裂発生時間は短くなり，乙 かも $100 \mathrm{~h}$ 遅れ破壊き裂発生強さ (100h (6000 min) を 経過してもき裂が発生しない最大の応力で, 以下単に $100 \mathrm{~h}$ 強さまたは $\sigma_{\mathrm{sec}}$ と略称する）は低下する7)，つぎ に，この遅れ破壞曲線を参考にして，前述 (Fig. 2) の部 分除荷法拈よび完全除荷法に拈ける試験応力 $\sigma\left(=\sigma_{\max }\right.$ $\left.-\sigma_{\mathrm{a}}\right)$ として, 90, 125, 160, 180 および $220 \mathrm{~kg} / \mathrm{mm}^{2}$ を選び（ただし，板厚が厚い場合には，切り欠き強さ $\sigma_{\mathrm{N}}$ が低いので，あまり大きな $\sigma_{\max }$ または $\sigma$ は選べな (), 除荷応力 $\sigma_{\mathrm{a}}$ を種々に変化させて遅れ破壊試験を行 い，そのときのき裂発生時間を調べた. その結果の数例 


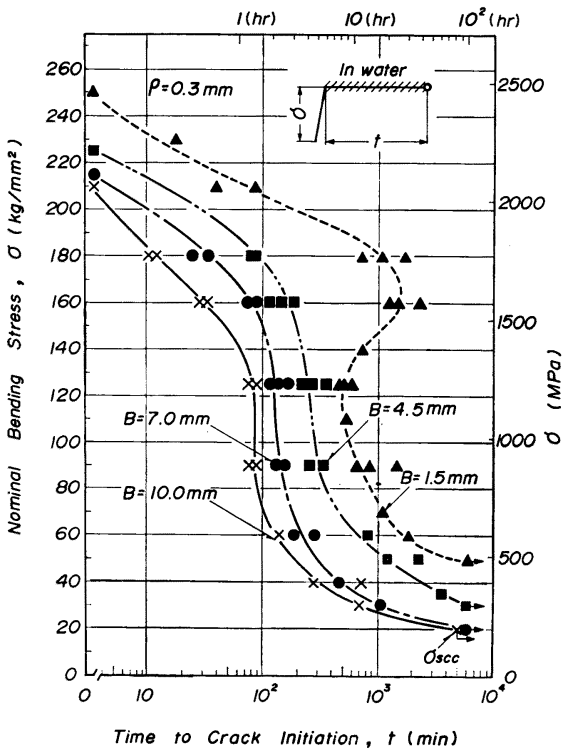

Fig. 3. Effect of specimen thickness on the relation between nominal bending stress and the time to crack initiation.



Fig. 4. Effect of unloading stress (or maximum stress, unloading ratio) on the time to crack initiation of the steel prestressed by partial unloading method.

をFig. 4，5，6(部分除荷法）および 7，8，9（完全除 荷法）に示す.なお，Fig. 7，8および 9 には比較のた め部分除荷法のときの結果も併記してある. これらの図 で $\sigma_{\mathrm{a}}=0$ のときのき裂発生時間は，予ひずみを与えな

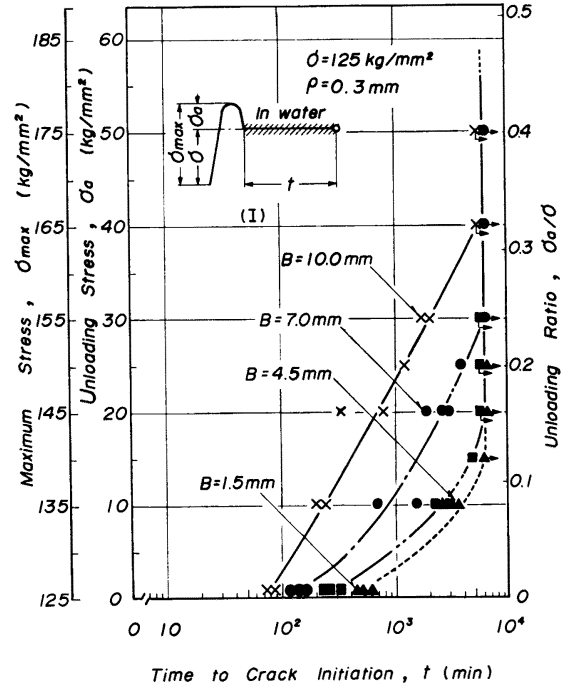

Fig. 5. Effect of unloading stress (or maximum stress, unloading ratio) on the time to crack initiation of the steel prestressed by partial unloading method.

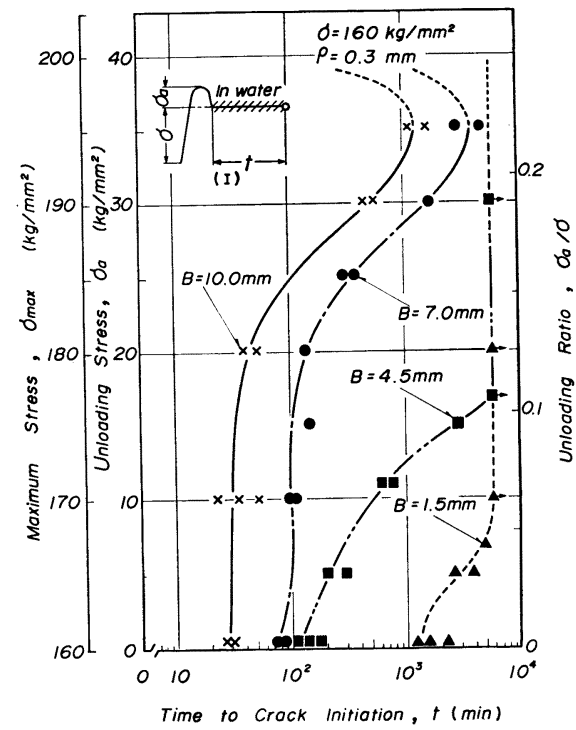

Fig. 6. Effect of unloading stress (or maximum stress, unloading ratio) on the time to crack initiation of the steel prestressed by partial unloading method.

い通常の遅れ破壊試験によつて得られた各試験応力 $\sigma て ゙$ のき裂発生時間 (Fig. 3 から求まる)である. 以上の実 験結果から，（Ｉ）部分除荷法，完全除荷法のいずれの場 合でも，またいずれの板厚でも，除荷応力 $\sigma_{\mathrm{a}}$ を適切に 選べば，き裂発生時間を $100 \mathrm{~h}$ 以上にすることができる 


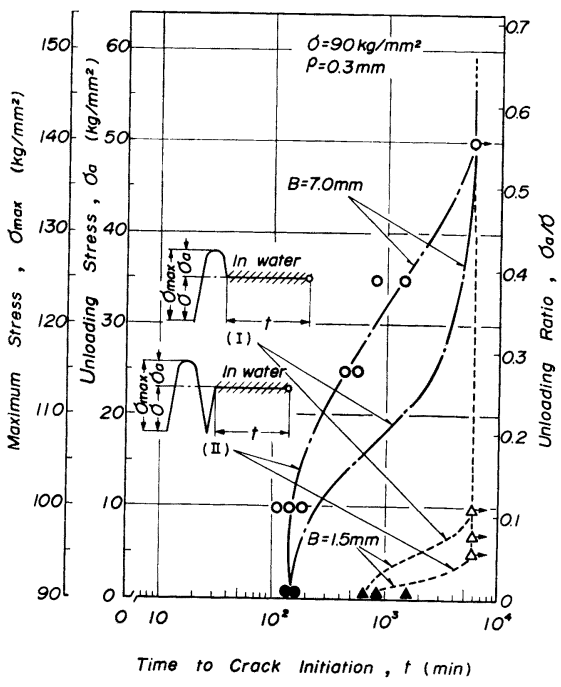

Fig. 7. Effect of unloading stress (or maximum stress, unloading ratio) on the time to crack initiation of the steel prestressed by perfect unloading method.

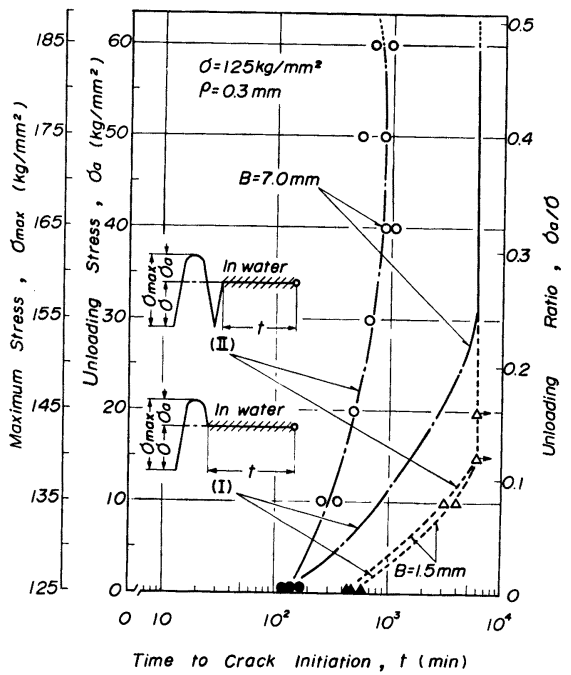

Fig. 8. Effect of unloading stress (or maximum stress, unloading ratio) on the time to crack initiation of the steel prestressed by perfect unloading method.

が，試験応力 $\sigma$ が大きくしかも板厚が大きい場合には， $\sigma_{\mathrm{a}}$ をどのように選んでも，もはやき裂発生時間を $100 \mathrm{~h}$ 以上とすることは不可能になることを，(2)き裂発生時 間を $100 \mathrm{~h}$ 以上にするに必要な最小の除荷応力，すなわ ち臨界除荷応力 $\left(\sigma_{\mathrm{a}}\right)_{\mathrm{e}}$ が存在し，それぞれの $\sigma$ に打いて 板厚が大きくなるほど $\left(\sigma_{\mathrm{a}}\right)_{\mathrm{c}}$ を大きくしなければなら ないことなどがわかる.

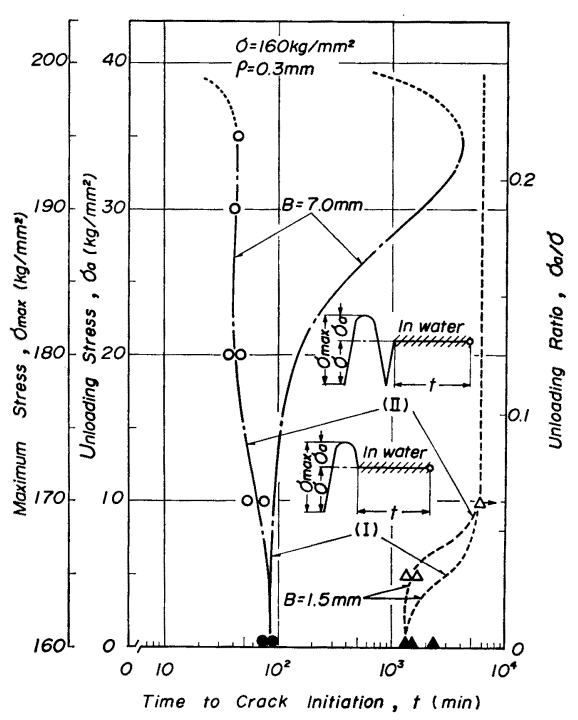

Fig. 9. Effect of unloading stress (or maximum stress, unloading ratio) on the time to crack initiation of the steel prestressed by perfect unloading method.

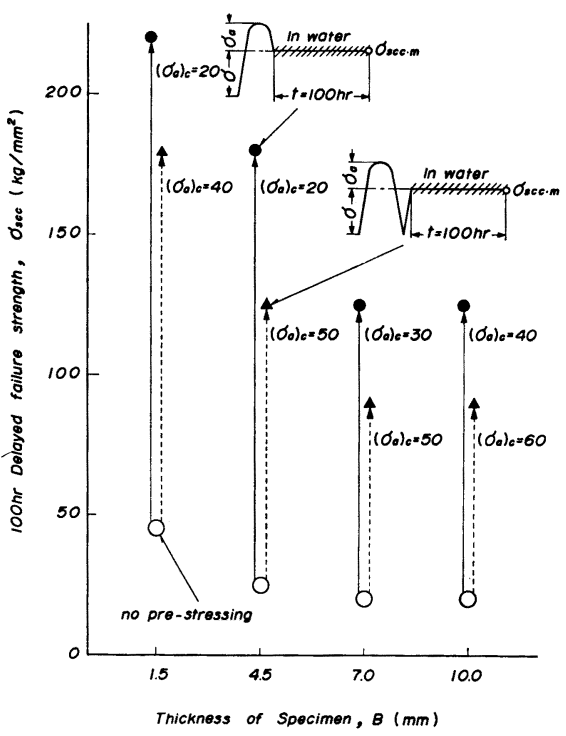

Fig. 10. Effect of specimen thickness on the increase of $100 \mathrm{~h}$ delayed failure strength (upper limit strength below which crack initiation does not occur within 100h) of the steel prestressed by partial unloading method or perfect unloading method.

Fig. 10 は Fig. 4〜9 などの結果をるとに, 種々の板 厚をもつ試験片の $100 \mathrm{~h}$ 強さが，部分除荷法拉よび完全 除荷法によつて最大どの程度まで上昇したかをまとめて 示したもので，この図によると，予荷重を加えないとき 


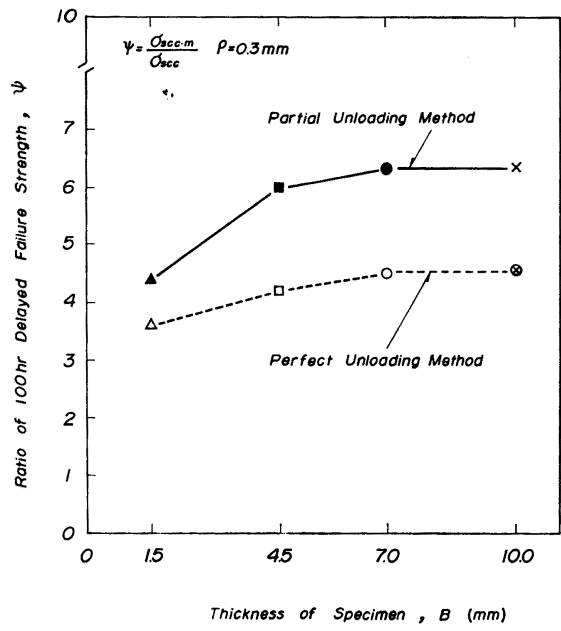

Fig. 11. Relation between specimen thickness and the ratio of $100 \mathrm{~h}$ delayed failure strength of prestressed steels to that obtained by usual delayed failure test.

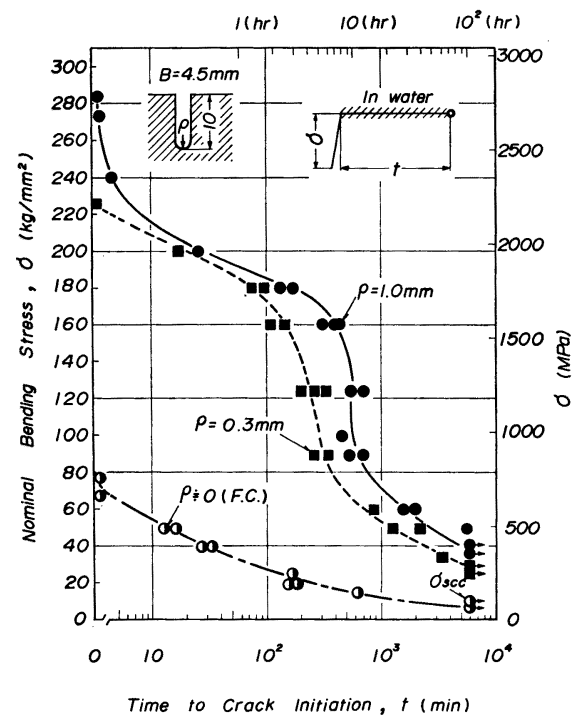

Fig. 12. Effect of notch root radius on the relation between nominal bending stress and the time to crack initiation.

の $100 \mathrm{~h}$ 強さ $\sigma_{\mathrm{scc}}$ は板厚が小さいほど大きいが，予荷 重を加えて得られる最大の $100 \mathrm{~h}$ 強さ $\sigma_{\mathrm{sec} \cdot \mathrm{m}}$ も板厚が 小さいほど大きいことがわかる，このことは，板厚が小 さいほど切り欠き強さが大きい(Fig. 3 参照)ので予荷 重応力 $\sigma_{\max }$ を大きくとることができることに関連する が，Fig. 10 の実験值に付記したように，最大の $100 \mathrm{~h}$ 強さ $\sigma_{\mathrm{scc} \cdot \mathrm{m}}$ が得られる最小の除荷応力すなわち臨界除

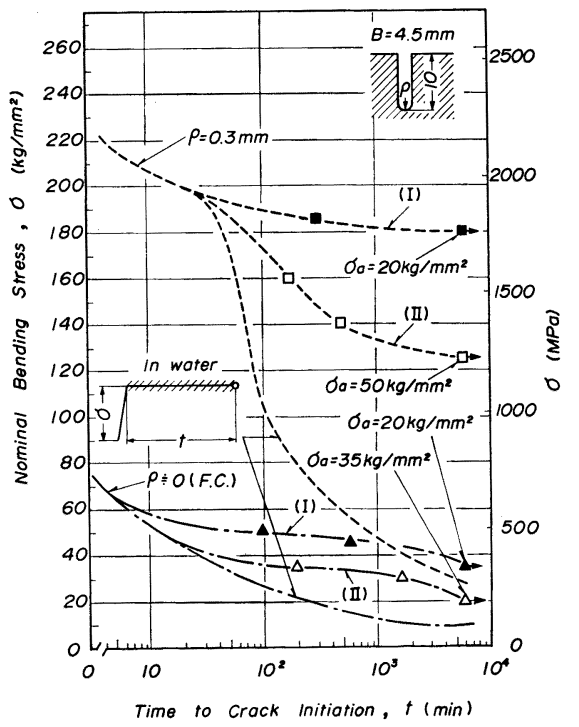

Fig. 13. Relation between nominal bending stress and the time to crack initiation in the specimens which were prestressed by partial unloading method or perfect unloading method.

荷応力 $\left(\sigma_{\mathrm{a}}\right)_{\mathrm{c}}$ が，板厚が小さいほど小さくてよいことに も関連している.このことについては後述する.

Fig. 11 は予荷重を加えたときの $100 \mathrm{~h}$ 強さの最大值 $\sigma_{\mathrm{scc} \cdot \mathrm{m}}$ と予荷重を加えないときの $100 \mathrm{~h}$ 強さ $\sigma_{\mathrm{scc}}$ の比 $\phi=\sigma_{\mathrm{secm}} / \sigma_{\mathrm{sec}}$ と板厚の関係を調べたものである. これ によると，すべての板厚において完全除荷法よりも部分 除荷法の方が $\phi$ が大きく， しかも板厚の増加とともに $\phi$ が大きくなつていて，荷重ひずみによる改善効果は，板 厚が大きくなるといくぶん大きくなる傾向が認められ る.

\section{2 遅れ破壊き裂発生時間におよぼす切欠き底曲率 半径および負荷方式の影響}

Fig. 12 は試験片の板厚 $B=4.5 \mathrm{~mm}$ とし, 切り欠き 底半径 $\rho$ を 0 (疲労き裂), 0.3 および $1.0 \mathrm{~mm}$ と変 化させて遅れ破壊試験を行い，試験応力 $\sigma$ とさ裂発生時 間の関係を求めた結果である.これによると， $\rho$ が大き いほどき裂発生時間执よび $100 \mathrm{~h}$ 強さ $\sigma_{\text {scc }}$ は大きくな る.

つぎに Fig. 13 特よび 14 は $B=4.5 \mathrm{~mm}$ で $\rho=〜 0$ (疲労き裂)，0.3 特よび $1.0 \mathrm{~mm}$ とし, 試験応力 $\sigma$ およ び除荷応力 $\sigma_{\mathrm{a}}$ の值を種々に变化させて行つた子荷重付 加の遅れ破壊試験の結果から，遅れ破壊き裂発生時間を もつとも長くすることのできた $\sigma$ と $\sigma_{\mathrm{a}}$ （その值は図中 に示してある）の組み合わせを選んで遅れ破壊曲線を作 




Fig. 14. Relation between nominal bending stress and the time to crack initiation in the specimens which were prestressed by partial unloading method or perfect unloading method.

り，これを予荷重を与えない場合の遅れ破壊曲線と比較 したものである. 両図より, 部分除荷法および完全除荷 法によつて子荷重を与えた材料の $100 \mathrm{~h}$ 強さは, 試験片 の切り欠き底曲率半径の大きさにかかわらず荷重を与え ないもののそれより大きく，それぞれ $4 \sim 6$ 倍 $(\phi=4$ ６）拈よび $2 \sim 4$ 倍 $(\phi=2 \sim 4)$ であることがわかる. なお，実験結果は省略するが，板厚 $B=4.5 \mathrm{~mm}$ で, 両側に深さ $8 \mathrm{~mm}$, 曲率半径 $\rho=0.3 \mathrm{~mm}$ の切り欠きを 有する試験片に引張り荷重による部分および完全除荷を ほどこして，遅れ破壊試験を行いき裂発生時間および $100 \mathrm{~h}$ 強さを求めた. この場合にも, 部分および完全除荷 法によりき裂発生時間は増加し $100 \mathrm{~h}$ 強さはそれぞれ予 荷重を与えない場合のそれらの約 2.4 倍 $(\phi \fallingdotseq 2.4)$ お よび 1.6 倍 $(\phi=1.6)$ に上昇した. 切り欠き底の応力 勾配は両側切り欠き引張試験片より曲げ試験片の方が大

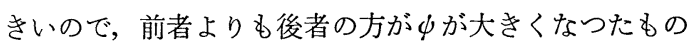
と考兄られが，これらのことから引張荷重が加わるよ らな部材に対しても部分および完全除荷法はな拉有効で あると思われる。

\section{4. 考察}

\section{1 予荷重によつて得られる $100 \mathrm{~h}$ 強さの最大値と 板厚および切り欠き底曲率半径の関係におよほ す除荷比の効果}

予荷重によつて最大の $100 \mathrm{~h}$ 強さを得るには，予荷重
応力 $\sigma_{\max }$ をできるだけ大きくして（たとえば切り欠き 強さ $\sigma_{\mathrm{N}}$ の $80 \sim 90 \%$ ), 除荷応力を一定の值（臨界除荷 応力）以上にとる必要がある5)。 ところで Fig. 10, 13 および 14 によると，板厚 $B$ が大きいほど切り欠き底曲 率半径 $\rho$ が小さいほど, $100 \mathrm{~h}$ 強さの最大值が得られる 最小の除荷比すなわち臨界除荷比 $\phi_{\mathrm{c}}=\left(\sigma_{\mathrm{a}} / \sigma\right)_{\mathrm{c}}$ を大き くしなければならないよらに思われる，そこで予荷重法 によつて $100 \mathrm{~h}$ 強さを最大にしよらとするときに， $\sigma_{\mathrm{a}}$ どのように選べばよいかの目安を与えるものとして，無 次元パラメータ $\delta=(\rho / B)^{n} \cdot\left(\sigma_{\mathrm{a}} / \sigma\right)_{\mathrm{c}}=(\rho / B)^{n} \cdot \phi_{\mathrm{c}}$ を考 える. $\rho / B$ は試験片の形状因子で $\rho / B$ が小さくなるほ ど切り欠き先端の応力状態が平面応力状態から平面ひず み ( 3 軸引張り) 状態に近づく. いま $n=1 / 2$ と仮定し, 実験值を入れて $\delta$ を計算すると，部分除荷法の場合で は, $\rho=0.3 \mathrm{~mm}$ のとき $B=1.5,4.5,7$ および $10 \mathrm{~mm}$

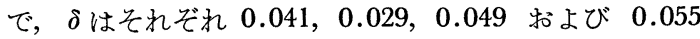
となる。また $\rho=1.0 \mathrm{~mm}, B=4.5 \mathrm{~mm}$ のとき $\delta=0.052$ となる. $\rho=0$ (疲労き裂),$B=4.5 \mathrm{~mm}$ の場合には $\rho$ の值をどの程度に評価すればよいか不明であるが，別 報7)で述べたように, $100 \mathrm{~h}$ 強さを与える疲労き裂の有効 曲率半径をかりに $0.04 \mathrm{~mm}$ にとると， $\rho=0.054$ とな る.すなわち試験片形状に応じて $\delta \geq 0.06$ となるよう に $\sigma_{\mathrm{a}}$ をとればき裂発生寿命が $100 \mathrm{~h}$ 以上になる. 同様 にして完全除荷の場合にも $\delta \geq 0.2$ となるように $\sigma_{\mathrm{a}}$ を 選べばき裂発生寿命が $100 \mathrm{~h}$ 以上になることがわかつ た.

遅れ破壊現象はメカノケミカルな現象であり，き裂の 発生が力学的因子にのみ依存しているとは思われないが 7), 上記のような整理法は除荷応力 $\sigma_{\mathrm{a}}$ の最適值を推定 するのにある程度役立つものと思われる.

\section{2 部分除荷法によつて遅れ破壊き裂発生寿命および 強さが增加する理由についての補足}

上述のように，予荷重を部分扎よび完全除荷法によつ て与えると，き裂発生時間扣よび $100 \mathrm{~h}$ 強さがかなり増 加し，その程度は部分除荷法の方が完全除荷法よりも大 である. その理由は著者らがすでに報告したよらに5), 負荷過程の違いによつて切り欠き底近傍の応力分布に差 が生じることがもつとも有力であろら.

Fig. 15 は，切り欠き先端近傍の応力分布が各負荷過 程（同図右上に示す荷重変化）でどのよらになつている かを推定して描いた前報5）の説明図を再録したものであ る．詳しい説明は前報で述べてあるので省略するが，曲 線(2)は予荷重を与えない通常の遅れ破壊試験のとき, 曲 線(4)は部分除荷法を施したときの応力分布である.これ らの曲線は同一外部荷重のもとでは切り欠き先端の応力 


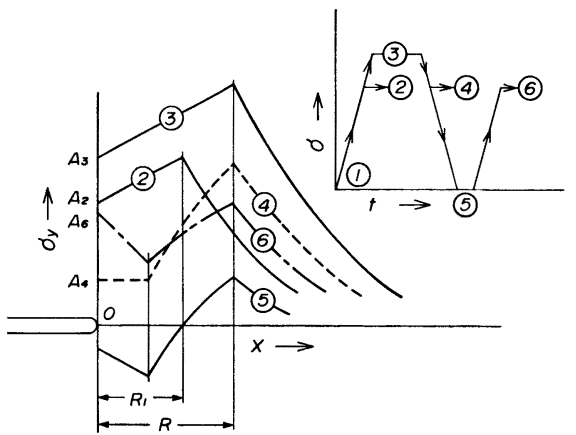

Fig. 15. Schematic illustration of stress distribution near notch root at various loading stages.

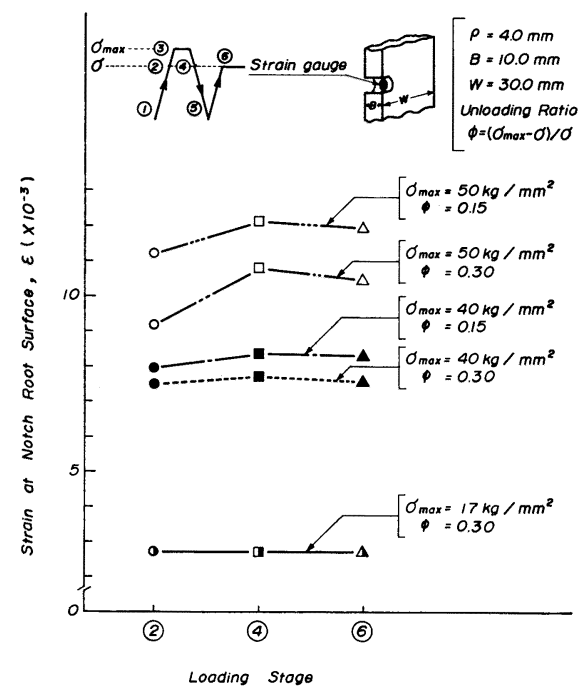

Fig. 16. Strain at notch root surface at various loading stages.

分布曲線の下の面積がいずれも等しくなるという荷重バ ランスから推定して描いたものであるが，曲線(4)は(2)に 比べ，切り欠き底表面の応力が小さく $\left(\overline{\mathrm{OA}}_{4}<\overline{\mathrm{OA}}_{2}\right) ， 乙$ かも切り欠き底表面から三軸応力場までの 距離が長い $\left(R>R_{1}\right)$. 一方，完全に除荷したときは曲線(5)のように 切り欠き底近傍に圧縮残留応力が生じているものと考兄 られるので，8）前報では再負荷後 $\sigma$ に拈ける応力分布す

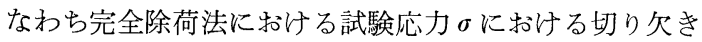
先端の応力分布は曲線(6)のうになつているものと推定 し，切り欠き底表面の応力の大きさの違いにより実験結 果を説明した. しかし，完全除荷法の場合の切り欠き底 表面の応力の大きさ $\overline{\mathrm{OA}}_{6}$ が, $\overline{\mathrm{OA}}_{4}<\overline{\mathrm{OA}}_{6}<\overline{\mathrm{OA}}_{2}$ となつ ているかどらかについてやや疑問が残つていたので，こ のことを明らかにするためにつぎのよらな実験をした。 すなわち, Fig. 16 上部右に示すように, $\rho=4 \mathrm{~mm}$ の

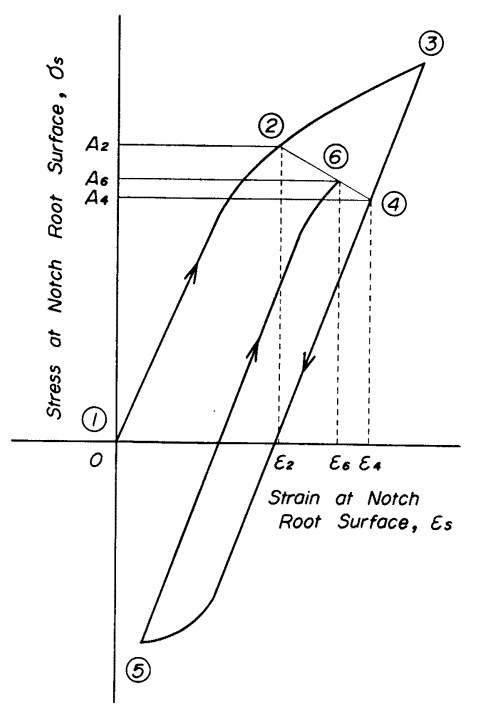

Fig. 17. Schematic illustration of stress-strain hysteresis loop at notch root surface.

切り欠き試験片の切り欠き底にひずみゲームを貼り，軸 方向の引張りひずみを測定した. なお Fig. 16 の横軸に 示す (2)，(4)拉よび (6は，同図上部左に示す負荷段階であ り，それぞれ通常の方法，部分除荷法，拉よび完全除荷 法における試験荷重に対応する. これによると, 最大応 力 $\sigma_{\max }$ (予荷重応力) が小さい場合には三者の間のひ ずみの違いは汪とんどないが， $\sigma_{\max }$ が大きくなるとひ ずみの大きさは部分除荷法, 完全除荷法, 予荷重なしの 順に小さくなつている.な抢このような傾向は, 試験片 の板厚 $B$ を $7 \mathrm{~mm}, 4.5 \mathrm{~mm}$ としても，また $B=4.5 \mathrm{~mm}$ で $\rho=2.9 \mathrm{~mm}$ としてもあまり変わらなかつた．この実 験事実は以下のように説明できる.

Fig. 17 は，上記の荷重変化 $($ (1) $\rightarrow$ (2) $\rightarrow$ (3) $\cdots \rightarrow$ (6) $)$ に よつて切り欠き底表面部の応力ーひずみ関係がどのよう になるかを，実測したひずみの值（Fig. 16)から予想し て描いた図である。すなわち(1) (2)では切り欠き底表面 部の材料は弾性変形するが, (2) $\rightarrow$ (3) と荷重が増加するに つれ，切り欠き底表面部の材料が塑性変形し，ひずみが 加速度的に増加する. 最大荷重(3に達したのち除荷する と弾性ひずみは回復するが，塑性ひずみは残留するので 荷重が零の点(5)では切り欠き底内部の弾性応力場が切り 欠き底表面部を圧縮し, 切り欠き底表面には圧縮応力が 作用することになる．このように，切り欠き底表面部の 材料は引張応力のあとで圧縮応力を受けるので, バウシ ンガー効果により，外部荷重が零でも切り欠き底表面部 は圧縮降伏し，したがつて図のように切り欠き底のひず 
みは荷重零で大きく減少する，ただし，(5)の点では，切 り欠き底には，引張りによるひずみと縮によるひずみ の差に相当するひずみ（実測によると引張りひずみ）が

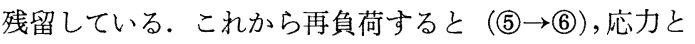
ひずみの関係は図のような経路をとつてほとんど直線的 に上昇するものと思われる. 同一外部荷重(2)，(4)および (6)での切り欠き底表面のひずみ $\varepsilon_{2}, \varepsilon_{4}$ 打よび $\varepsilon_{6}$ の関係 は，実測によると $\varepsilon_{2}<\varepsilon_{6}<\varepsilon_{4}$ であり (Fig. 15)，(2) と (4)の状態での切り欠き底表面の実際の応力 $\sigma_{\mathrm{S} \cdot 2}\left(\overline{\mathrm{OA}}_{2}\right)$ 打 よび $\sigma_{\mathrm{S} \cdot 4}\left(\overline{\mathrm{OA}}_{4}\right)$ は $\sigma_{\mathrm{S} \cdot 4}<\sigma_{\mathrm{S} \cdot 2}$ であるので, Fig.17 より $\sigma_{\mathrm{S} \cdot 4}\left(\overline{\mathrm{OA}}_{4}\right)<\sigma_{\mathrm{S} \cdot 6}\left(\overline{\mathrm{OA}}_{6}\right)<\sigma_{\mathrm{S} \cdot 2}\left(\overline{\mathrm{OA}}_{2}\right)$ であることは明らか である.すなわち, 完全除荷法を施したときの試験公称 応力 $\sigma$ に打㳊切り欠き底表面の応力 $\sigma_{\mathrm{S}}$ は, 通常の方 法拉よび部分除荷法を施したときのそれらの中間の值を とる. もちろん予荷重のときの最大荷重が小さいときに は, 切り欠き底表面の材料はほぼ弾性変形し, Fig. 17の ようなとステリシスループは描かず $\sigma_{\mathrm{S} \cdot 4}\left(\overline{\mathrm{OA}}_{4}\right) \approx \sigma_{\mathrm{S} \cdot 6}$ $\left(\overline{\mathrm{OA}}_{6}\right) \approx \sigma_{\mathrm{S} \cdot 2}\left(\overline{\mathrm{OA}}_{2}\right)$ となる. したがつて，前報5) で議論 したように，切り欠き底表面の応力が小さいほど切り欠 き底表面での腐食反応が抑制され, $100 \mathrm{~h}$ 強さが大きくな つたものと思われる。

なお，実験結果によると，板厚が大きい㳯ど予荷重に よる $100 \mathrm{~h}$ 強さの上昇率 $\phi$ はいくぶん大きく，またこの ような大きな $100 \mathrm{~h}$ 強さを達成するには, 板厚が大きい ほどまた切り欠き底表曲率半径が小さいほど, 臨界除荷 比 $\left.\phi_{\mathrm{c}}=\sigma_{\mathrm{a}} / \sigma\right)_{\mathrm{c}}$ を大きくしなければならない，その理由 は, 各試験片形状, 各予荷重法で切り欠き底の応力分布 が異なるためと思われるが，詳細は現在までのところ明 らかではない、しかし，いずれにしろ，部分除荷法およ び完全除荷法は，切り欠きやき裂を含む一般の部品や部 材の遅れ破壊強さを向上させるのに，広く適用できる方 法であると思われる。

\section{5. 結言}

燒入れ後 $200^{\circ} \mathrm{C}$ で焼もどしした SNGM 8 切り欠き 材に, 部分除荷法扰よび完全除荷法で予荷重を与えて遅 れ破壊試験を行い，そのときのき裂発生時間呿よび 100 $\mathrm{h}$ 遅れ破壊強さが試験片の形状（板厚叔よび切り欠き底 半径の大きさ）によつてどのように変化するかを調べ た. 得られた主な結果はつぎのとおりである.

（1）部分和上び完全除荷法，とくに部分除荷法で予 荷重を与えた材料のき裂発生時間拈よび $100 \mathrm{~h}$ 強さは, 予荷重を与えないもののそれらよりかなり大きい。この ことは, 試験片の板厚や切り欠き底曲率半径の大きさに 無関係に成立するが，予荷重による $100 \mathrm{~h}$ 強さの上昇の 割合は，板厚が大きいほど大きくなる傾向がある.

（2）部分拉よび完全除荷法によつて, $100 \mathrm{~h}$ 強さを最 大限に上昇させるには, 板厚が大きいほど, また切り欠 き底曲率半径が小さい注ど, 除荷応力 $\sigma_{\mathrm{a}}$ を大きくする 必要がある。

\section{交献}

1) たと光ば，山本俊二：鉄と鋼，55(1969)，p. 326

2) C. S. GARTer: Met. Trans., 3(1973), p. 584

3 ) 南雲道彦, 門田安弘: 水素による遅破填の機構 (1975), p. 149 日本鉄鋼協会鉄鋼基礎共同研究会 遅机破壊部会編

4 ) 木戸光夫, 中佐啓治郎, 武井英雄: 日本金属学会 誌, 41 (1977), p. 987

5 ) 中佐啓治郎, 木戸光夫, 武井英雄：鉄と鋼， 64 (1978), p. 578

6 ) $K$. NAKasa, $H$. TAKeI, and $M$. Kido: Engineering Facture Mechanics, 11(1979), p. 733

7 ) 中佐啓治郎, 武井英雄, 桜武達規: 材料, 28 (1979), p. 299

8 ) J. R. RICE: Fatigue Crack Propagation, ASTM STP415, (1967), p. 247 